\title{
The Impact of Audio-Visual Aids in Learning English among MSU Third-Year Students
}

\author{
Mohammed H. Al-Aqad \\ Management and Science University, Malaysia \\ alakkadmohmad@msu.edu.my \\ Mohammad A. Al-Saggaf \\ Xiamen University Malaysia, Malaysia \\ mohammad.aliabdellah@xmu.edu.my \\ Muthmainnah \\ Universitas Al Asyariah Mandar, Indonesia \\ muthmainnahunasman@gmail.com
}

\begin{abstract}
This study investigates the efficacy of audio-visual technologies in assisting MSU third-year students in learning English vocabulary. The interplay of audio-visual aids in educational conversations has been researched from a variety of perspectives (Tuovinen, 2000). Multimedia is a multimodal experience in which information is communicated through text, graphics, pictures, audio, and video. It has been demonstrated that a combination of words and images always carries a substantial quantity of information (Mayer, 2018: 55). The use of multimedia in teaching and learning. The goal of this research is to determine the efficiency of audiovisual aids in the learning of English vocabulary among MSU third-year students. The use of multimedia in instruction and learning threatens the foundations of higher education. The current study investigates how third-year students at Malaysia's Management and Science University use multimedia in their English studies (MSU). To fulfill the study's aims, the researchers used both a qualitative and quantitative approach. An online poll of 200 students enrolled in the Bachelor of English as a second language program was used to construct the study corpus (BTESL). In addition, $150 \mathrm{MSU}$ students from the same program were polled. The study's findings
\end{abstract}

ENGLISH FRANCA : Academic Journal of English Language and Education

Vol. 5, No. 2, 2021, IAIN Curup

P-ISSN 2580-3670, E-ISSN 2580-3689

DOI: $10.29240 /$ ef.v5i2.3329 
indicate that multimedia inspires BTESL students to learn English creatively and engagingly. It also aroused students' attention and compelled them to learn new terms. Multimedia, according to the study, is an excellent tool for third-year English students. It also helps students enhance their understanding of correct terminology and language.

Keywords: Multimedia in learning, BTESL students, education technology, MSU University

\section{INTRODUCTION}

Vocabulary is one of the key linguistic components that form the foundation of foreign language acquisition. Having a good vocabulary helps students understand oral as well as textual communication Year after year, the number of students learning English as a Foreign language has gradually increased. These kids must acquire not just linguistic abilities but also academic skills to succeed in university. Reading academic literature, producing effective academic prose, and conducting research all require the use of English to acquire and communicate information. The purpose of this study is to look at the influence of employing multimedia in English language acquisition among MSU students. Although Bahasa Malaysia is the official language of Malaysia, English is extensively utilized in academics. The Ministry of Education is working to increase English language usage among the younger generation. Since 2010, they have been transforming the school system to improve academic achievement and quality. English has established itself as a worldwide communicative language. As a result, Malaysia is working toward Vision 2020 for student education growth. To minimize language obstacles when enrolling in colleges in our nation, school children are expected to study English as well as Malay. Recently, the Malaysian Ministry of Education announced plans to switch the language of instruction for Mathematics and Science disciplines from Malay to English.

Around the world, an increasing number of universities are experimenting with online education. As a platform, the World Wide Web is employed for online learning to disseminate materials in the form of web pages that include Texts, hyperlinks, images, animations, audios, videos, games, and quizzes are all possible. Email and discussion boards are also used in online learning to improve student-teacher and student-student communication. Some online courses adhere to a full distance education paradigm in which classroom connections are completely replaced by computer-mediated communications, whilst 
AlAqad, M., Al-Saggaf, M. and Muthmainnah (2021): The impact of Audio-Visual Aids in Learning English among MSU Third-Year Students

others adhere to a hybrid English taught as a second language in Malaysian schools. When it comes to writing in English, students confront several obstacles. As a result, (Buckley, 2013) revealed that "English is a mandatory subject in Malaysia from Primary One to Form Five." Despite this, many school dropouts, particularly in rural regions, cannot talk or write in English." According to this statement, several academics believe that English has been taught largely for exam purposes, with teachers focusing entirely on what comes out for tests and not teaching students for lifetime English usage.

"Primary problems in L2 (Second Language) writing education include improper teaching approach and the usage of traditional resources," write (Vijaya \& Shahin Sultana, 2016). According to this remark, some academics feel that even after pupils have been exposed to English language writing for around 11 years, they are still unable to create effective writing since they have spent the entire time studying inappropriately with incorrect material selections. For example, rather than using visual resources, the teacher teaches essay writing structure verbally so that students may understand it better.

In a recent article published on September 7, While the Ministry of Education will continue to strengthen the position of Bahasa Malaysia as a national language, English will be given equal weight to create a global generation according to the Minister of Education in 2013. He underlined that more time is allocated for English lessons in schools to improve student's language ability. The change is designed to prepare students for 2016 when passing English for "Sijil Pelajaran Malaysia" would become required (SPM).

Since its independence in 1957, Malaysia has seen significant economic and social progress, notably in the previous three decades. Malaysia's government has made great progress in digital development as part of its objective of becoming a developed nation by 2020. The government's National Information Technology Agenda, established in 1996, set the basis for Malaysia's fast development of the ICT industry. In 2014, the government budget allocation for the IT industry was RM 4.9 billion, accounting for $10 \%$ of overall expenditure allocation in the budget.

\section{Problem Statement}

English is recognized as a necessary language not only in the educational context but also in society as a whole. Individuals must guarantee that they speak English fluently. Furthermore, learning English has always been a challenging endeavor for individuals, especially if the student hails from a well-educated family. English as a Second Language (ESL) teachers in Malaysia acknowledges that pupils 
struggle to comprehend and express themselves in English. Students are hesitant to voice their thoughts because of the language barrier. As a result, future generations of Malaysians will have a strong incentive to learn the language.

The major cause of low academic achievement is a lack of English language competence. As we all know, the English language is primarily employed at many colleges. Students, on the other hand, are having difficulty putting their words up without any grammatical faults. Due to a lack of English competence, the majority of students lose confidence while presenting. Although they are well-versed in their subject, they tend to receive lower grades due to issues with pronunciation, grammar, word choice, and communication in English. This is since anyone may communicate their views in English by writing or speaking it, but in some instances, particularly formal settings, It is critical for a person to express precisely what he or she intended to say and, more importantly, for those who read it to understand it. This will express not just a person's appearance, but also his or her educational level.

\section{THEORETICAL FRAMEWORK}

The literature study helps to elaborate on the potential impacts of employing multimedia to improve students' writing skills in the future. As stated previously in the introduction, English language writing is an area in which Malaysian students fall short. This is due to a variety of factors, including interference from the native tongue, a lack of knowledge and conception of ideas for what to write, poor syntax, a lack of linguistic accuracy, a limited vocabulary, and a variety of other issues According to Writing (2016), "repetitive mistakes and habits, such as improper grammar and spelling, poorly organized essays, and unsubstantiated ideas, were some of the writing challenges students experienced."

According to Thirusanku and Melor (2012), English is used as a second language in several multilingual nations, including Malaysia, India, the Philippines, Nigeria, and others. Gill and Kirkpatrick (2013) performed research to find a balance between national and international demands and difficulties exhibited via language education policy. English has been designated a compulsory subject at all levels in Malaysia. This remark indicates that Malaysians have enacted educational policies to increase English language proficiency among the bilingual population.

According to Bernd Ruschoff and Markus Ritter (2010), technology-assisted language learning has a favorable influence on vocabulary, comprehension, spelling, and pronunciation. Berrion and 
AlAqad, M., Al-Saggaf, M. and Muthmainnah (2021): The impact of Audio-Visual Aids in Learning English among MSU Third-Year Students

Mehmet (2013) did a similar investigation, which demonstrated that technological tools and symbol systems give appropriate language signals. Because language learning is an important element High-tech, mid-tech, and low-tech communication systems are used in human communication. Speaking, reading, and listening are all essential components of language teaching and learning. This demonstrates the importance of technology, such as audio and video, in language learning. Technology Enhanced Learning, according to Boonyopakorn (2016) The influence of technology on language teaching and learning is an issue for language. Technology-enhanced learning has been shown to turn the classroom into a student-centered atmosphere, stimulating and extending students' interest in learning. Technology has made it possible to teach and practice English.

According to Niloofar and Dara (2014), the majority of instructors consider technology-enhanced language learning to be highly effective in teaching English. Technology in the classroom has been shown to assist both instructors and students by developing a positive attitude toward learning. Research on "English Teachers' Barriers to Computer-Assigned Language Learning" was done. This was written by Kuang Wu Le. Though teachers encounter considerable challenges when engaging in computer-assisted language learning, it is critical to the country's educational transformation. Creating instructional materials requires more time and work, but it gives more possibilities for greater practice with the language

According to Abbas Pourhosein (2012), teachers must employ multimedia to create a realistic learning environment for pupils to learn a language more naturally and effectively. Not only can create an authentic learning environment, but the use of technology can also facilitate the teachers to build up and improve students' characters as well (kendiani, et.al, 2021; Apriani, et.al, 2019; Fathurrochman, I., \& Apriani, E, 2017). It is curious to use a combination use of interactive teaching approaches to attain optimum student learning goals By utilizing multimedia learning, students will be able to evaluate their weaknesses and strengths. Simhachalam Thamaran (2016) verified in research that multimedia technologies improve language learning and aid in individual motivation for pupils. Solanki and M Phil's research "Use of Technology in English Language Teaching and Learning" (2012). Accordingly, it can be said that ICT has a positive side for the students (Apriani, et.al, 2016, Gusmuliana, et.al, 2020, Apriani and Hidayah, 2019; Apriani et; al, 2020). The study's goal was to highlight the benefits and drawbacks of multimedia, which provided a better pattern for exploring a new teaching paradigm. 
Vijayakumari and Nachimuthu (2011) found in "Role of Educational Games Improves Meaningful Learning" that educational games may help kids acquire spelling, reading, and other skills. To promote creative education, the author suggests that teachers include educational games in their teaching and learning processes. The use of video content, according to Lumturie and Merita (2016), aids in the Processes of learning and teaching. The purpose of this study is to look into the advantages that audio and visual aids have for language teachers and learners when teaching and learning English. This instructor can keep their pupils interested and immersed in activities, allowing them to be more active, motivated, and confident in their communicative language competence.

\section{RESEARCH METHODOLOGY Subjects/Sample}

The research was carried out at Malaysia's Management and Science University. The study corpus was produced via 200 students enrolled inside the Bachelor of English as a Second Language program who completed an online survey (BTESL).

\section{Research Instruments}

The purpose of the research tools the researcher's role in this research project is to get the study's official results. The researcher used both tools to reduce the goals and obtain fair-based results study findings to support the research design to achieve an official result. This study included both quantitative and qualitative methods.

To begin, a questionnaire is defined as a series of questions with multiple-choice responses. The goal is to find out what people think about the study. The questionnaire was created by performing surveys on prior research, internet reads, and information sharing from previous researchers. The survey was carried out among TESL Bachelor students. The survey Using Multimedia to Motivate Students in EFL Classrooms was created by Bouzar Mohammed Amine1, University of Béchar Cambridge. These techniques helped modify and revise the questionnaire. Those polls fit into a certain category.

Finally, an interview is described as seeing someone face to face and asking them a purposeful question. As a consequence, it is possible to acquire their point of view and exchange knowledge about a subject. Each of the 15 students will be asked five interview questions. These difficulties, which are based on multimodal perception, need a clear explanation. 
AlAqad, M., Al-Saggaf, M. and Muthmainnah (2021): The impact of Audio-Visual Aids in Learning English among MSU Third-Year Students

\section{RESULTS AND DISCUSSION Results}

The majority of BTESL students feel their teachers employ multimedia in the classroom, according to the report. According to this survey, 69.5 percent of lecturers constantly use multimedia in the classroom. According to this research, students are learning in the classroom using multimedia since 18.5 percent of lecturers solely utilize multimedia sometimes and 24 percent of lecturers utilize multimedia regularly frequently. As a result of the study's findings, 100 percent of respondents think that a multimedia is a beneficial tool for improving educational learning. According to the research, a large majority of students believe that multimedia instruction is useful to their education; nevertheless, Only $5 \%$ of students agree with the statement. As previously stated, around $90 \%$ of BTESL students think that multimedia assists in the long-term preservation of information, whereas $10 \%$ of BTESL students completely disagree. Tables and figures should be valuable, relevant, and visually attractive.

\section{Table 1}

\begin{tabular}{cccc}
\hline \multicolumn{4}{c}{ Research } \\
\hline Column 1 & Column 2 & Column 3 & Column 4 \\
\hline Content 1 & $10 \%$ & $6 \%$ & $3 \%$ \\
\hline Content 2 & $6 \%$ & $8 \%$ & $3 \%$ \\
\hline Content 3 & $7 \%$ & $9 \%$ & $4 \%$ \\
\hline
\end{tabular}

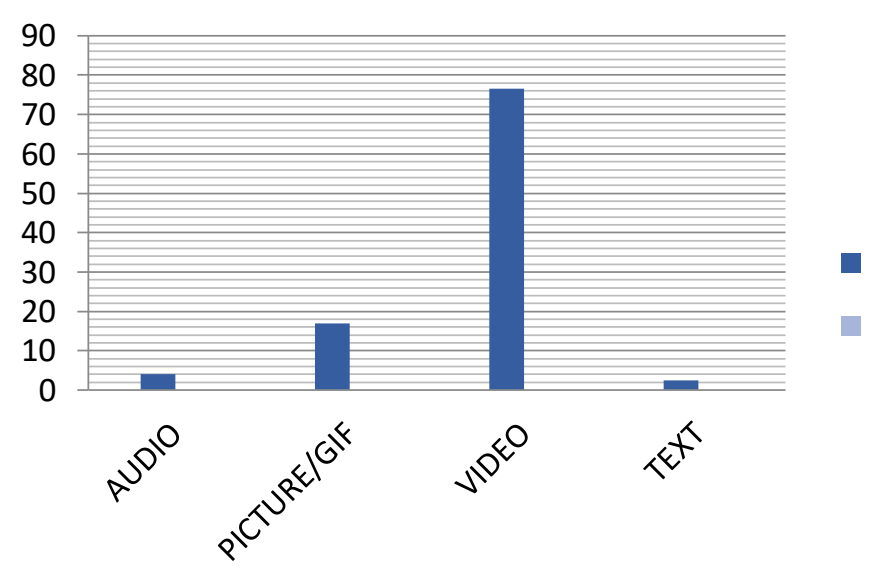

Figure 1. Kind of Multimedia 
The Ministry of Education is debating whether or not to promote Early childhood English language acquisition using multimedia. According to the findings, about 87.5 percent of all respondents believe that the Ministry of Education should emphasize English language learners in early childhood through multimedia. Whereas 12.5 percent of students were vehemently opposed. All of the students think that instructional videos make lectures easier to grasp since they demonstrate a variety of practical ways to behave and solve difficulties while studying English. According to the questions above, among the many types of multimedia, Video was the top-ranked tool, followed by Pictures and Audio. Text is the least popular kind of multimedia among MSU BTESL students.

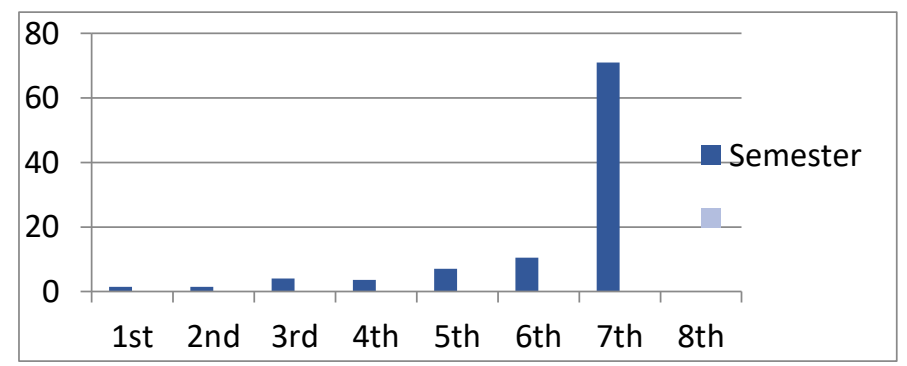

Figure 2. Students' Semester

There were, according to the findings (71 percent) Students in the seventh semester (10.5 percent ) Students in the sixth semester (7.0 percent) ( 4.0 percent ) Students in the third semester (3.5 percent) Students in the fourth semester (1.5 percent) This question is answered by Sem 1 and Sem 2 students, as well as (1.0\%) Sem 8 students. The largest number of students responded to the survey during Semester 7.

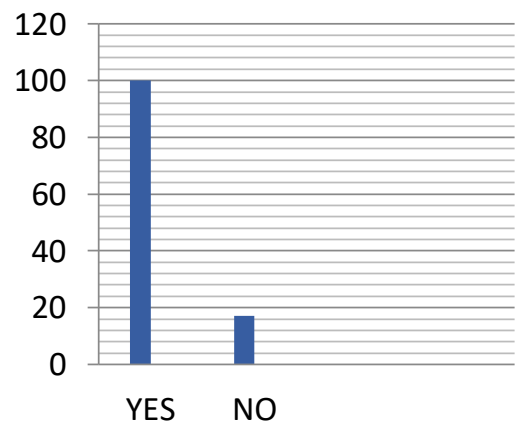

Do you think multimedia is an effective tool in learning English language?

Figure 3 
AlAqad, M., Al-Saggaf, M. and Muthmainnah (2021): The impact of Audio-Visual Aids in Learning English among MSU Third-Year Students

According to the poll, $100 \%$ of respondents believe that multimedia may aid improve educational learning.

\section{Discussion}

The current study looks at the role of multimedia in English language acquisition among MSU BTESL students. The study's data was obtained utilizing both qualitative and quantitative methods. The qualitative technique was used by the researcher to obtain student opinions on the use of technology in the classroom The quantitative technique was then utilized to collect data by delivering an online survey to 200 Bachelor students and conducting interviews with about 150 Bachelor students from the TESL program at Management and Science University (MSU).

A deeper understanding of the process, on how the use of multimedia helps in the English language, have come across with these three main domains of factors: what is the most appropriate multimedia used in the classroom, the benefit of using multimedia among BTESL students, and what are students' perceptions of multimedia. To solve the issues mentioned previously, A study was carried out to look into the link between multimedia and the English language. The findings, on the other hand, were highly convincing and persuading, indicating that multimedia did help pupils to produce a positive learning outcome in which students were able to improve their command of the English language

According to the study's findings, multimedia inspires BTESL students to learn English more creatively and interestingly. It also helps kids to learn new terminology and phrases by increasing their observation. This may be done by incorporating multimedia into the teaching and learning process. According to the study's findings, a multimedia is a great approach for teaching English to Students of BTESL. This is because it helps students enhance their ability to acquire proper vocabulary and grammar. Overall, video (multimedia) has been proved to be an excellent medium for learning English, and students utilize it to augment their second language vocabulary knowledge. Students learn best when they understand the importance and value of the information presented in class. As a result, for students to achieve their learning goals, it is critical to employ a range of teaching approaches to foster an inspirational and collaborative classroom environment.

According to data, the majority of BTESL students believe that technology utilized in English classes inspires them, with 87.5 percent believing that technology always enhances their desire to study English. 
Some student enrollments are declining responses, on the other hand, suggesting that the multimedia method should be revisited. Students were not taught how to use media during their bachelor's degree classes. As a result, teachers may want to progressively expand their use of multimedia.

Overall, 94 percent of students feel that using technology in every session would improve their English language skills. The researcher also found a small reduction in this question, which was connected to studying for a bachelor's degree. As a result, before graduation, teachers should increase their usage of multimedia. According to the students, this move will spark their interest in studying English and drive them to attend every session, and they will not miss any lectures owing to the numerous technological gadgets used and the different manner in which lectures are delivered. 92.5 percent of students think that technology tools are always needed in classrooms to assist their comprehension and learning process in studying English. These pupils want to see various technology devices utilized to motivate them. This conclusion validates our interpretations of the preceding results, which summarize the regression to how the media is utilized.

PowerPoint presentations, according to all students, may make courses and lectures more entertaining. For example, I've been teaching these same kids a research skills class for three years, and I've used many PowerPoint presentations in class. As a consequence, the students like the PowerPoint lectures and have no trouble understanding them. Furthermore, due to the many manners in which lectures are presented and the visual aids used in teaching, 95 percent of students believe that technology always makes lectures enjoyable. When researching research methodologies, for example, Students who are unfamiliar with research paper formatting may benefit from viewing training videos that teach how to design a research paper and how to pick the margins.

\section{CONCLUSION}

This study found that integrating technology in the classroom may be a very motivating element for BTESL students at MSU. Technology has the potential to improve education in several ways. Most importantly, the inclusion of technology has the potential to increase student motivation. All students attend the class regularly since the course appears to be engaging, as opposed to the typical classroom atmosphere, which appears to be uninteresting and for which the students lack the required abilities to succeed. PowerPoint presentations, training videos, and audio files are among the tools used 
AlAqad, M., Al-Saggaf, M. and Muthmainnah (2021): The impact of Audio-Visual Aids in Learning English among MSU Third-Year Students

in the course to improve knowledge and understanding. The youngsters were confident in their skills to finish their projects since they were working with technology. Students delivered their exposés in class using PowerPoint presentations and Internet-downloaded videos. The students were ecstatic at the idea of putting their abilities to the test, and they found the task to be both hard and fascinating.

BTESL students want their teachers to use technology in the classroom as well. Most students who use technology become more motivated, and they recognize that a computer-connected projector is the most crucial piece of classroom equipment. This study also discovered that a variety of technical gadgets, including computers, projectors, video, films, and multimedia, appeared to influence foreignlanguage acquisition. According to student replies, there is a substantial link between language learning motivating factors and technology use. To summarize, utilizing technology in BTESL lessons makes language acquisition more relevant and exciting, and students are more driven as a result of this technological advancement in English classes. The following recommendations are made based on the study's findings:

- Technology should be included in the BTESL curriculum to create a vibrant classroom environment and to facilitate learning.

- For optimum success in English courses, university instructors should emphasize the significance of employing technology and should use realistic and participatory activities.

- Materials accessible on the Internet should be chosen based on the kids' requirements and interests.

- Teachers should not believe that utilizing technology is the sole way to motivate students; courses should be founded on well-designed technology classrooms as well as pedagogical issues

- Technology that stimulates students' attention should be used to help an effective teaching-learning process.

- Through online education, language learners can be encouraged to engage in active learning.

The findings also give information that teachers may utilize to improve this and other courses in the future. Finally, educators will continue to use a wide range use of multimedia learning technologies to improve the educational experience, to prepare In their professional careers, students will be expected to engage in rigorous critical thinking, problem-solving, and lifelong learning. 


\section{REFERENCES}

Apriani, E. (2016). A New Literacy: The role of technology to develop students character. Ta'dib: Journal of Islamic Education (Jurnal Pendidikan Islam), 21(1), 59-72.

Al-Saggaf, M. A., Al-Aqad, M. H., \& Govindasamy, V. (2020). The Key Factors Affecting English Reading Comprehension Among Malaysian Students. Psychology and Education Journal, 57(9), 2496-2503.

Apriani, E., \& Hidayah, J. (2019). The ICT Used by the English Lecturers for Non-English Study Program Students at IAIN Curup. Vision: Journal for Language and Foreign Language Learning, 8(1), 26-37.

Bikowski, D., \& Vithanage, R. (2016). Effects of web-based Collaborative writing on individual L2 writing development, Language Learning \& Technology, 20(1),79-99,Bladerunner,(2009,December 14).Funny Construction Accidents.

Bird, J. and Edwards, S (2014) Children learning to use technologies through play: A Digital Play Framework. British Journal of Educational Technology; 46:1149-1160, doi: 10.1111/bjet.12191

Carisma, D. (2009) Teaching reading strategies and reading comprehension within a technology- enhanced learning environment.

Conole, G. (2013), Designing for learning in an open world, springer, New York.

Dylan, Sung. (2012) Perception of Using Online Technology in Language Education: An interview study with Taiwanese University Students.

Elmagzoub, A. (2015) For Effective use of multimedia in Education, Teachers Must Develop Their Own Educational Multimedia Applications. 
AlAqad, M., Al-Saggaf, M. and Muthmainnah (2021): The impact of Audio-Visual Aids in Learning English among MSU Third-Year Students

Fathurrochman, I., \& Apriani, E. (2017). Pendidikan Karakter Prespektif Pendidikan Islam dalam Upaya Deradikalisasi Paham Radikal. Potensia: Jurnal Kependidikan Islam, 3(1), 122.

Helaluddin, H., Al Aqad, M. H., Wijaya, H., Anwar, J., Nadya, N. L., \& Syafryadin, S. (2021). Development and Validation of Academic Writing Textbook Based on Process Genre Approach for University Students. AL-ISHLAH: Jurnal Pendidikan, 13(2), 10681079.

Gill, s.k \& Kirkpatrick, A (2013) English in Asian \& European Higher Education-Inc.A Chappelle (EU).The Encyclopaedian of Applied Linguistic

Gulcin. (2009) New trends in 21st Century English Learning.

Gusmuliana, P., Apriani, E., \& Karolina, A. (2020). Islamic fefac as an interesting learning media to improve students'english ability and develop their character values in man rejang lebong. Jurnal Inovasi Pengabdian Masyarakat Pendidikan, 1(1), 36-44.

Jonitha, E, and Greany, F. (2002) Students Perception on Language Learning in a Technological environment: Implications for the new millennium.

Kendiani, S. D. (2020). The Islamic Characters in Teaching English. Journal of English Education and Teaching, 4(3), 431-448.

Lumturie, A. (2016) The Role of Video Material in EFL classroom.

Mayer. R \& Moreno, RE. (2000) A Coherence Effect in Multimedia Learning Journal of Educational Psychology.

Mayer. R, (2005), “Cognitive theory of multimedia learning, Mayer R (ed), Cambridge handbook of multimedia learning. 2nd,ed New York : Cambridge University Press p169-182

Rudchoff, R. \& Markus, R. (2010) Technology Enhanced Language Learning Construction of Knowledge and Template, Germany.

Shu, Ching. (2006) Technology Enhanced language learning; A case study 
Shahzad, A. (2012) The Sample Thesis on Education Analysis of The Problem in Speaking English.

Xiannong, J. (2017). Study on Effective Using of Multimedia Teaching System and Enhancing Teaching Effect. China.

Tuovinen, J. E. (2000). Multimedia distance education interactions. Educational Media International, 37(1), 16-24. 